OPEN ACCESS

Edited by:

Wenjun Zhang,

Nanjing University of Information

Science and Technology, China

Reviewed by:

Lin Chen,

Nanjing University of Information Science and Technology, China

Xiaojing Jia,

Zhejiang University, China

*Correspondence:

Shangfeng Chen

chenshangfeng@mail.iap.ac.cn

Specialty section: This article was submitted to Atmospheric Science, a section of the journal

Frontiers in Earth Science

Received: 06 November 2021 Accepted: 15 December 2021

Published: 03 February 2022

Citation:

Chen S, Chen W, Ying J, Zheng Y and Lan $X$ (2022) Interdecadal Modulation of the Pacific Decadal Oscillation on the

Relationship Between Spring Arctic Oscillation and the Following

Winter ENSO

Front. Earth Sci. 9:810285 doi: 10.3389/feart.2021.810285

\section{Interdecadal Modulation of the Pacific Decadal Oscillation on the Relationship Between Spring Arctic Oscillation and the Following Winter ENSO}

\author{
Shangfeng Chen ${ }^{1,2 *}$, Wen Chen ${ }^{1,2}$, Jun Ying ${ }^{3,4}$, Yuqiong Zheng ${ }^{1,2}$ and Xiaoqing Lan ${ }^{1}$ \\ ${ }^{1}$ Center for Monsoon System Research, Institute of Atmospheric Physics, Chinese Academy of Sciences, Beijing, China, ${ }^{2}$ College \\ of Earth and Planetary Sciences, University of Chinese Academy of Sciences, Beijing, China, ${ }^{3}$ State Key Laboratory of Satellite \\ Ocean Environment Dynamics, Second Institute of Oceanography, Ministry of Natural Resources, Hangzhou, China, ${ }^{4}$ Southern \\ Marine Science and Engineering Guangdong Laboratory, Zhuhai, China
}

Previous studies indicated that Arctic Oscillation (AO) in boreal spring is an important extratropical trigger for the outbreak of El Niño and Southern Oscillation (ENSO) events in the succedent winter. This study reveals that the Pacific Decadal Oscillation (PDO) has a strong modulation on the linkage between the spring $A O$ and the following winter ENSO. Particularly, impact of the spring $\mathrm{AO}$ on the succedent winter ENSO is strong during positive PDO phase (+PDO). By contrast, the spring AO-winter ENSO connection is weak during negative $\mathrm{PDO}$ phase (-PDO). During +PDO, positive spring $\mathrm{AO}$ induces a marked anomalous cyclone over the subtropical North Pacific via wave-mean flow interaction. The subtropical cyclonic anomaly leads to sea surface temperature (SST) warming and enhanced atmospheric heating there, which could further propagate southward to the tropical central Pacific via wind-evaporation-SST feedback mechanism and, thus, impact the following winter El Niño via the tropical process. During -PDO, the spring AOgenerated SST, the atmospheric circulation, and the heating anomalies over the North Pacific are much weaker. As such, spring AO has weak impacts on the winter ENSO. The spring climatological storm track is stronger during +PDO than -PDO years due to an increase in the mean meridional temperature gradient over the North Pacific. Stronger storm track intensity during +PDO leads to stronger synoptic-scale eddy feedback to the mean flow, which results in stronger AO-related SST and atmospheric anomalies over the North Pacific and, thus, the stronger impact of the spring AO on the following winter ENSO.

Keywords: Arctic Oscillation, El Niño and Southern Oscillation (ENSO), Pacific decadal oscillation, storm track, air-sea interaction

\section{INTRODUCTION}

The El Niño and Southern Oscillation (ENSO) is the leading atmosphere-ocean coupling pattern over the tropical Pacific on the interannual timescale (Bjerknes, 1969; Philander, 1990; Neelin, 1998; Wang et al., 2000; Chen and Lian 2020; Fang and Xie 2020; Zhang et al., 2020; Hu et al., 2021). ENSO events could notably impact occurrences of extreme weather and climate events over many parts of 
the world via modulating the tropical Walker circulation and triggering extratropical atmospheric teleconnections, and usually exert severe damages to the agriculture, terrestrial and marine ecosystems, and economic development (Zhang et al., 1996; Horel and Wallace, 1981; Zhang et al., 1997; Chen et al., 2000; Wang et al., 2000; Alexander et al., 2002; Huang et al., 2004; Yu and Zwiers, 2007; Zhou and Chan, 2007; Zhang et al., 2011, 2012; Cheung et al., 2012; Chen et al., 2013; Zhai et al., 2016; Chen et al., 2017; Song et al., 2017; Tang et al., 2018, Chen et al., 2019a, Chen et al., 2019b; Hu et al., 2020; Wei et al., 2020; Hu et al., 2021; Yang and Huang 2021, and references therein). Therefore, understanding the impact factors for the ENSO variability and improving the prediction skill of ENSO occurrence are of great importance.

In addition to the well-known positive atmosphere-ocean interaction and the oceanic processes within the tropical Pacific (Bjerknes, 1979; Philander, 1990; Schopf and Suares, 1988; Jin, 1997; Ren et el. 2016), more and more recent studies reported that the atmosphere-ocean forcings over extratropics also play considerable roles in modulating the onset, development, and phase transition of a specific ENSO event (Vimont et al., 2001, 2003; Alexander et al., 2010; Wang et al., 2011; Chang et al., 2007; Yu et al., 2012; Chen et al., 2014, Chen et al., 2020a, Chen et al., 2020b; Su et al., 2014; Yeh et al., 2015; Ding et al., 2015; Min et al., 2017; Zheng Y. Q. et al., 2021, Zheng Y et al, 2021; and references therein). For instance, Li et al. (1990) indicated that a stronger East Asian winter monsoon (EAWM) is more favorable for occurrence of an El Niño event in the following winter via triggering westerly wind bursts over the tropical western Pacific. The wintertime North Pacific Oscillation (NPO), the second Empirical Orthogonal Function (EOF) mode of sea level pressure (SLP) anomalies over extratropical North Pacific (Wallace and Gutzler 1981; Linkin and Nigam, 2008; Song et al., 2016; Chen and Wu, 2018), was suggested to exert a marked impact on the outbreak of ENSO events during the following winter via the seasonal footing mechanism (SFM) (Vimont et al., 2001, Vimont et al., 2003; Alexander et al., 2010). Wang et al. (2011) suggested that summertime sea surface temperature (SST) anomalies in the mid-latitude North Atlantic could trigger a Eurasian atmospheric teleconnection, which impacts the EAWM and the following winter ENSO occurrence. Studies also indicated that atmosphere-ocean systems over extratropics of Southern Hemisphere have a close relation with the following winter ENSO (e.g., Ding et al., 2015; Min et al., 2017).

The Arctic Oscillation [AO, also known as the Northern Annular Mode (NAM)] is the first EOF mode (EOF1) of atmospheric variability over extratropical Northern Hemisphere (Thompson and Wallace, 1998, Thompson and Wallace, 2000). Spatial structure of the AO is featured by an oscillation in the SLP and geopotential height anomalies between high- and mid-latitudes of Northern Hemisphere with a vertical barotropic structure (Thompson and Wallace, 1998, Thompson and Wallace, 2000). The wave-mean flow interaction is an important source in forming and maintaining the AO-related atmospheric circulation anomalies over mid-high-latitudes (Limpasuvan and Hartmann 1999; Lorenz and Hartmann
2003; Thompson et al., 2003). In addition to the significant impact of the $\mathrm{AO}$ on the weather and climate anomalies over extratropics (Thompson and Wallace, 1998, Thompson and Wallace, 2000), recent studies indicated that climate systems over tropics are also remarkably modulated by the AO (Nakamura te al. 2006; Gong et al., 2011; Choi et al., 2012; Chen et al., 2014). In particular, Nakamura et al. (2006) demonstrated that the boreal spring $\mathrm{AO}$ has a significant impact on the following winter ENSO outbreak via modulating the westerly wind anomalies over the tropical western Pacific. Chen et al. (2014) further analyzed the physical processes for the impact of the spring $\mathrm{AO}$ on the subsequent winter ENSO in detail. They demonstrated that the interaction between synoptic-scale eddy and low-frequency mean flow and related vorticity transportation play a key role in the generation of the atmospheric anomalies over the subtropical North Pacific and zonal wind anomalies over the equatorial western Pacific. The zonal wind anomalies over the equatorial western Pacific further impacts following winter ENSO outbreak via triggering eastward propagating and downwelling Kelvin waves (Barnett et al., 1989; Huang et al., 2001; Lengaigne et al., 2004; Nakamura et al., 2006; Chen et al., 2015). Chen et al. (2016a) revealed that the strong AO event in spring of 2015 plays an important role in the outbreak of the strong 2015-2016 EL Niño event via triggering strong westerly wind burst over the equatorial western Pacific.

However, the relationship between the spring $\mathrm{AO}$ and winter ENSO is unstable (Chen et al., 2015, Chen et al., 2020c). Specifically, Chen et al. (2015) reported that the spring AO-winter ENSO connection has undergone a pronounced interdecadal change around the 1970s. Spring AO-related atmospheric circulation anomalies over the North Pacific are much stronger after than before the 1970s (Chen et al., 2014), contributing to a stronger spring AO-winter ENSO connection after the interdecadal change. Moreover, studies have demonstrated that change in the connection between the spring $\mathrm{AO}$ and winter ENSO is essentially attributed to change in the climatology of the storm track intensity over North Pacific (Chen et al., 2015, Chen et al., 2017, Chen et al., 2020b). In particular, stronger springtime North Pacific storm track intensity could lead to a stronger feedback of the synopticscale eddy to mean flow (Chen et al., 2015, Chen et al., 2017). This leads to stronger atmospheric anomalies over North Pacific related to the spring $\mathrm{AO}$, including the zonal wind anomalies over the equatorial western Pacific, and thus results in a stronger impact of the spring AO on the winter ENSO (Chen et al., 2015, Chen et al., 2017).

The Pacific Decadal Oscillation (PDO) is the leading EOF mode of SST anomalies in the North Pacific on the decadal time scale (Mantua et al., 1997). Studies have indicated that the PDO has a strong impact on the North Pacific storm track intensity and North Pacific atmosphere on the decadal time scale (Budikova 2005; Zhou et al., 2007; Wang et al., 2008; Lee et al., 2012; Ding et al., 2014; Kim et al., 2014). Hence, we speculate that the PDO may have an impact on the spring AO-winter ENSO connection via modulation of the North Pacific storm track intensity and via modulation of the spring AO-related atmospheric anomalies over 
the North Pacific. In this analysis, we will present observational evidences to show that the PDO indeed has a marked modulation effect on the spring AO-winter ENSO connection. The physical processes for the modulation of the PDO are also examined.

The structure of the rest of this paper is organized as follows. The Data and methodology section describes the data and methods employed in this study. The Spring AO-ENSO connection in different phases of $P D O$ section investigates the interdecadal modulation effect of the PDO on the spring AO-winter ENSO connection. The Mechanisms for the modulation of the PDO section examines the physical mechanisms for the modulation of the PDO on the spring AO-winter ENSO relation. The Summary section provides a summary.

\section{DATA AND METHODOLOGY}

This study employs the monthly average SST from the National Oceanic and Atmospheric Administration (NOAA) Extended Reconstructed SST version five dataset (ERSSTV5) (Huang et al., 2017; https://www.esrl.noaa.gov/psd/data/). ERSSTV5 SST data have a resolution of $2 \times 2$ and a span from 1854 to the present. Monthly and daily average SLP, geopotential height, winds, precipitation rate, and surface heat fluxes are extracted from the National Centers for Environmental Prediction and National Center for Atmospheric Research (NCEP-NCAR) reanalysis (Kalnay et al., 1996), with a horizontal resolution of $2.5 \times 2.5$ and available from 1948 to the present (https://psl.noaa.gov/data/ gridded/data.ncep.reanalysis.html). The monthly average PDO index from 1900 to the present is obtained from the Joint Institute for the Study of the Atmosphere and Ocean (http://research.jisao. washington.edu/pdo/).

The Niño-3.4 SST index, defined by SST anomalies averaged over $5^{\circ} \mathrm{S}-5^{\circ} \mathrm{N}$ and $170^{\circ}-120^{\circ} \mathrm{W}$, is employed to represent the ENSO variability. An El Niño (a La Niña) event is identified when the 3-month running mean of the Niño-3.4 SST index are above $0.5^{\circ} \mathrm{C}$ (below $-0.5^{\circ} \mathrm{C}$ ) on five consecutive 3 -month periods. The spring AO is defined as the first EOF mode of spring SLP anomalies north of $20^{\circ} \mathrm{N}$. Correspondingly, the spring AO index is defined as the principal component (PC) time series of the first EOF mode. Positive (negative) spring AO years are selected when the normalized spring AO index are larger (less) than 0.5. Synoptic scale eddy activity (also called storm track) is calculated as the 2- to 8-day band-pass filtered daily geopotential height (Chang and Fu 2002; Lee et al., 2012; Chen et al., 2014). Positive (negative) PDO years are selected when the 9-year running mean PDO index is larger (less) than zero. Long-term trends and interdecadal components of all the variables, except PDO index, are removed by a 9-year high-pass Lanczos filter (Duchon, 1979). Significance levels of the linear regression and correlation are estimated based on the two-tailed Student's t-test. To ensure that the close connection between the spring AO and following winter ENSO is not due to the ENSO cycle, the preceding winter ENSO signal (represented by the Niño-3.4 SST index) has been linearly removed from the spring $\mathrm{AO}$ index and other variables. For example, the preceding winter ENSO signal was removed from the spring AO index as follows:

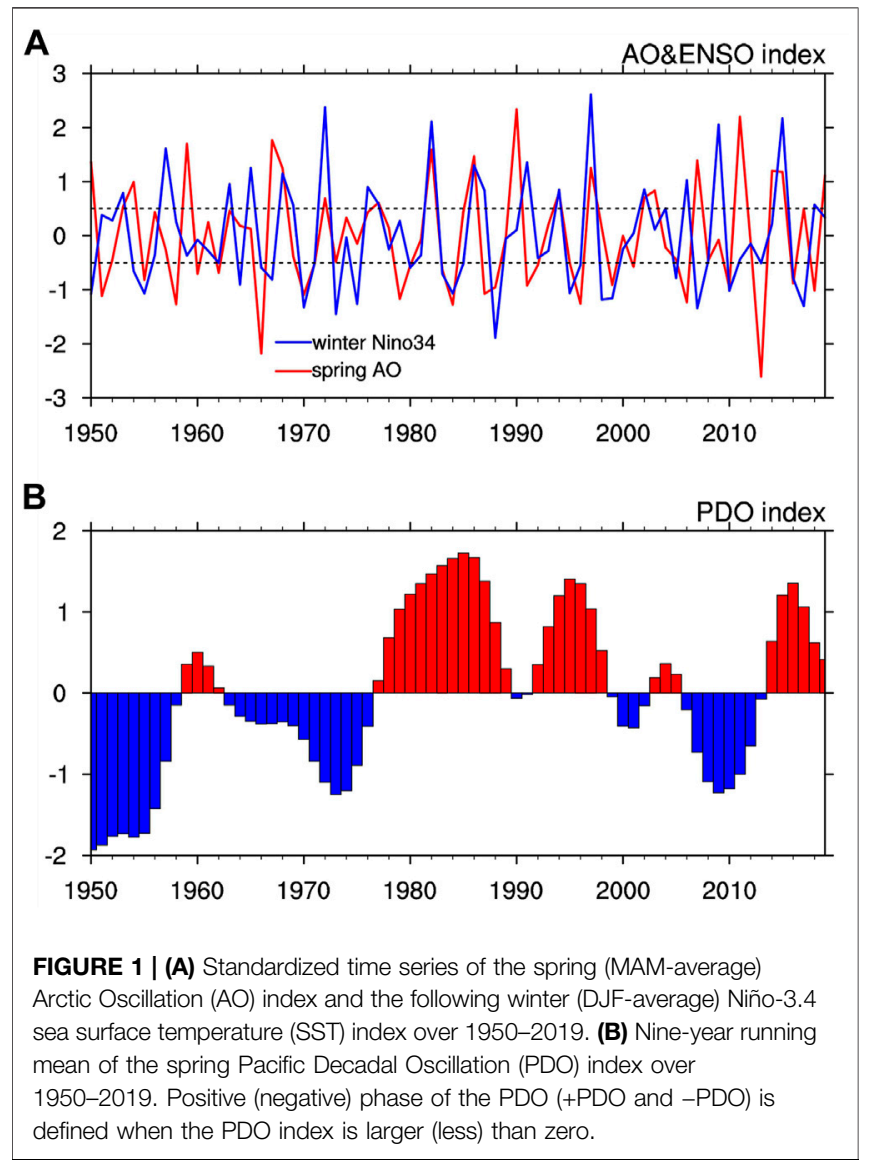

$A O_{\text {res }}=A O-\operatorname{Reg} \times$ Niño-3.4. Here, $A O$ indicates the spring $\mathrm{AO}$ index, Niño-3.4 indicates the preceding winter Niño-3.4 SST index. Reg is the regression coefficient between the preceding winter Niño-3.4 SST index and the spring AO index. $A O_{\text {res }}$ is the part of the spring AO that ENSO signal has been linearly removed.

\section{SPRING ARCTIC OSCILLATION-EL NIÑO AND SOUTHERN OSCILLATION CONNECTION IN DIFFERENT PHASES OF THE PACIFIC DECADAL OSCILLATION}

Standardized time series of the spring [March-April-May, $\operatorname{MAM}(0)] \quad A O$ index and subsequent winter [December-January-February, $\mathrm{D}(0) \mathrm{JF}(1)$ ] Niño-3.4 SST index are exhibited in Figure 1A. From Figure 1A, many positive spring AO years (i.e., 1953, 1963, 1968, 1972, 1977, 1982, 1994, 1997, 2002, 2009, 2014, and 2015) are followed by El Niño events in the following winter. In addition, a number of La Niña events are preceded by negative spring AO years (i.e., 1955, 1970, 1983, 1984, 1988, 1995, 1999, 2005, 2008, 2010, 2016). The correlation coefficient between the spring $\mathrm{AO}$ index and the following winter Niño-3.4 SST index is about 0.27 for the period of 1950-2016, significant at the $95 \%$ confidence level. Hence, this suggests that the spring $\mathrm{AO}$ has a close connection with the following winter ENSO, in concert with previous studies although according to 

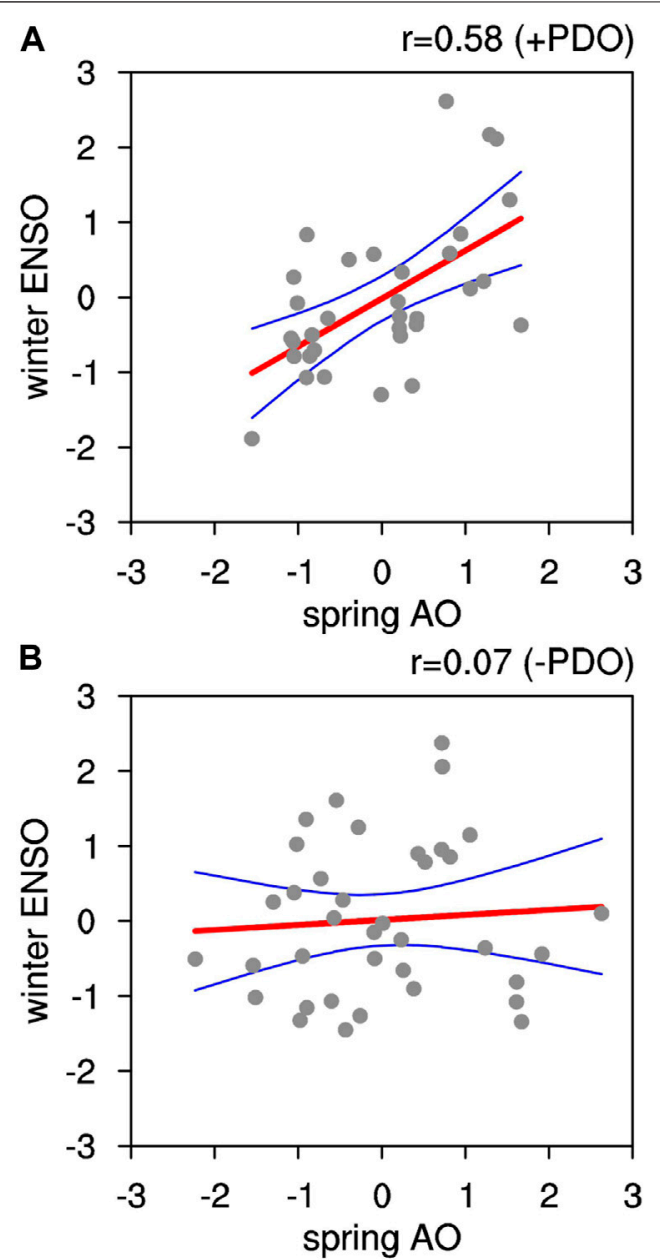

FIGURE 2 | Scatter plots of the spring $A O$ index with the following winter Niño-3.4 SST index for the (A) +PDO and (B) -PDO years, respectively. Red lines indicate the best linear fit. Blue lines indicate the $95 \%$ confidence range of the linear regression.

different datasets and time periods (Nakamura et al., 2006; Chen et al., 2014, Chen et al., 2017).

According to Figure 1A, positive (negative) spring AO years are not always followed by an 1) El Niño (La Niña) event in the succedent winter. This indicates that the spring AO-winter ENSO connection is unstable. Chen et al. (2015) reported that the impact of the spring $\mathrm{AO}$ on the subsequent winter ENSO enhanced significantly after the 1970s, corresponding to transition of the PDO from its negative to positive phases (Figure 1B). Moreover, during the positive phase of the PDO (+PDO) (Figure 1B), the positive spring AO years in 1982, 1997, and 2015 are followed by strong El Niño events (Figure 1A). By contrast, during the negative phase of the PDO (-PDO), the positive spring AO years in 1959, 1967, 1990, and 2011 are not followed by El Niño events (Figures 1A,B). The correlation coefficient between the $\operatorname{MAM}(0)$ AO index and the $\mathrm{D}(0) \mathrm{JF}(1)$ Niño-3.4 SST index reaches 0.58 for the +PDO years (33 years), significant at the $99.9 \%$ confidence level (Figure 2A). However, the relationship of the spring AO with the following winter Niño-
3.4 SST index is very weak for the -PDO years (37 years), with a correlation coefficient of only 0.07 (Figure 2B). Particularly, difference in the correlation coefficient of the spring $\mathrm{AO}$ index with the Niño-3.4 SST index between +PDO and -PDO years are significant at the $99 \%$ confidence level according to Fisher's r-z transformation.

Therefore, above statistical analyses indicate that the PDO acts as an important modulator for the impact of the spring $\mathrm{AO}$ on the following winter ENSO. Under + PDO background, spring AO has a close connection with the following winter ENSO. In sharp contrast, impact of the spring AO on the following winter ENSO is very weak under -PDO background.

\section{Mechanisms for the Modulation of the Pacific Decadal Oscillation}

In this section, the plausible mechanisms for the modulation of the PDO on the spring AO-winter ENSO connection are examined. Evolutions of 850-winds, SST, and precipitation anomalies from simultaneous spring to the following winter regressed upon the spring AO index for the +PDO and -PDO years are shown in Figures 3-5, respectively. Evolutions of the winds, SST, and precipitation anomalies in association with the spring $\mathrm{AO}$ for the +PDO years are similar to those reported in previous studies (Chen et al., 2014, Chen et al., 2015, Chen et al., 2017), showing a marked impact of the spring $\mathrm{AO}$ on the following winter ENSO. For the $+\mathrm{PDO}$ years, positive spring $\mathrm{AO}$ years are related to a notable meridional dipole atmospheric anomaly pattern over North Pacific with a strong anticyclonic anomaly over mid-highlatitudes North Pacific (corresponding to the North Pacific component of the spring AO) and a marked cyclonic anomaly over subtropical North Pacific (Figure 3A). Note that spatial structures of the spring AO-related atmospheric anomalies at the $500-\mathrm{hPa}$ and $200-\mathrm{hPa}$ (not shown) are highly similar to those at the $850-\mathrm{hPa}$ (Figure 3A), indicative of a barotropic vertical structure (Thompson and Wallace 1998, Thompson and Wallace 2000). As reported in previous studies (Chen et al., 2014, Chen et al., 2015, Chen et al., 2017), generation of the spring AOrelated cyclonic anomaly over subtropical North Pacific is attributable to the interaction between synoptic-scale eddy activity and low frequency mean flow as well as the associated vorticity transportation. Specifically, the anticyclone anomaly over the mid-high-latitudes North Pacific is associated with strong easterly wind anomalies to its south side between $35^{\circ}-45^{\circ} \mathrm{N}$ (Figures 3A and 6B). These easterly wind anomalies are accompanied by significant decrease in the storm track activity (Figures 6A-D) (Chen et al., 2014). As has been demonstrated by previous studies (Lau 1988; Cai et al., 2007; Chen et al., 2014, Chen et al., 2015), the decrease in the storm track activity is immediately accompanied by cyclonic vorticity forcing to its south side and anticyclonic vorticity forcing to its north side. Therefore, the cyclonic vorticity forcing to the south side of the storm track explains the formation of the spring AO-related cyclonic anomaly over the subtropical North Pacific (Chen et al., 2014). In addition, the anticyclonic vorticity forcing to the north side of the storm track helps maintain the anticyclonic anomaly over mid-highlatitude North Pacific (i.e., North Pacific component of the spring 


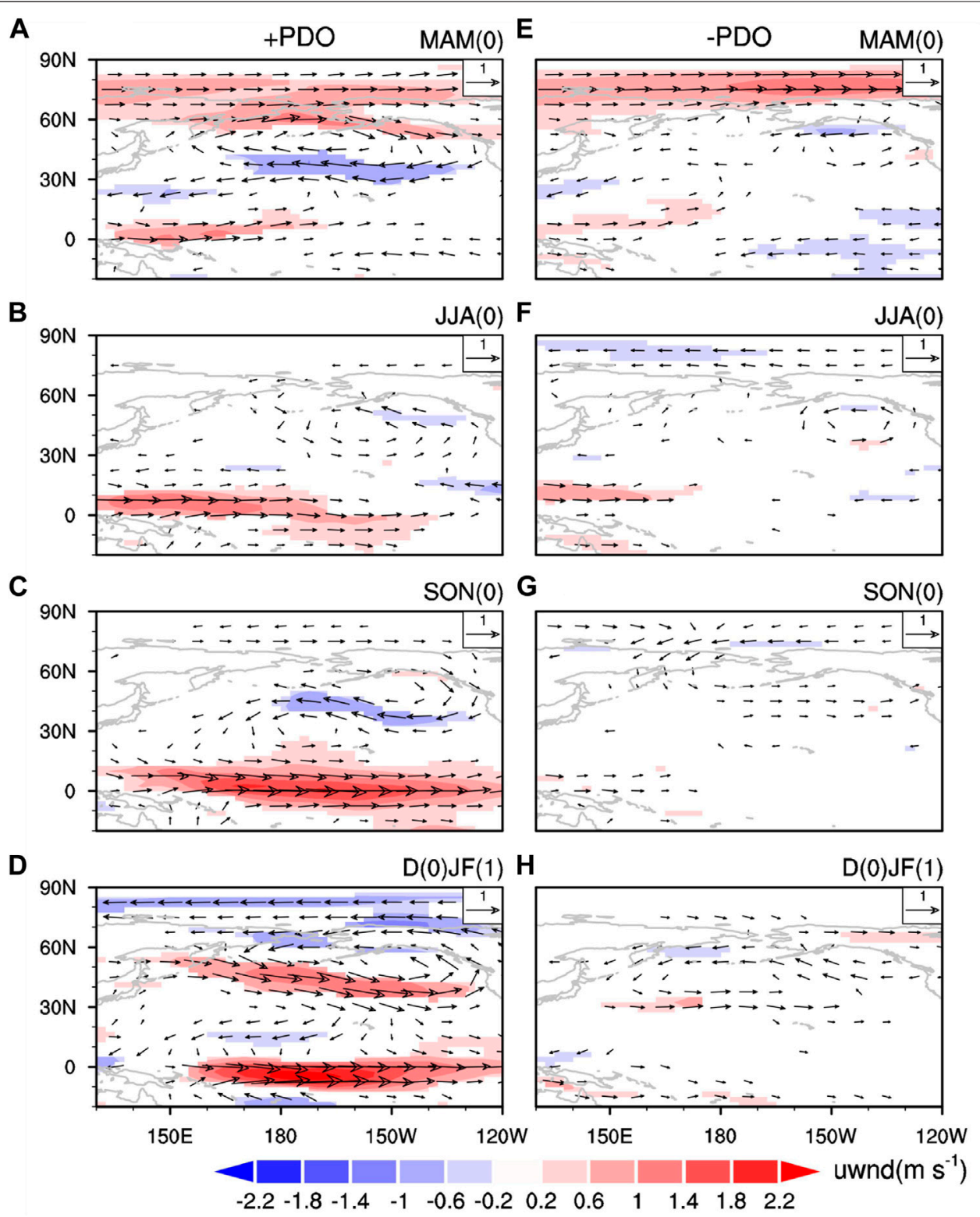

FIGURE 3 |Winds of 850-hPa (vectors, $\mathrm{ms}^{-1}$ ) and 850-hPa zonal wind (shadings, $\mathrm{ms}^{-1}$ ) anomalies in (A,E) spring [MAM(0)], (B,F) summer [JJA(0)], (C,G) autumn $[\mathrm{SON}(0)]$, and (D,H) winter [D(0)JF(1)] regressed upon the spring AO index for the (left column) +PDO and (right column) -PDO years. We only show the 850-hPa zonal wind anomalies that are significant at the $95 \%$ confidence level.

AO). Hence, the interaction between synoptic scale eddy and mean flow help maintain the spring AO-related atmospheric anomalies over North Pacific. This is consistent with the prevailing view that the wave-mean flow interaction plays an important role in the generation and maintenance of the AO-related atmospheric anomalies over extratropics (Limpasuvan and Hartmann 1999; Lorenz and Hartmann 2003).

The cyclonic anomaly over the subtropical North Pacific generated by the spring AO could directly lead to strong westerly wind anomalies over the tropical western Pacific (Figure 3A). These westerly wind anomalies over the tropical western Pacific could exert notable impacts on the occurrence of the following winter El Niño event (Figures 4C,D) via stimulating eastward propagating and downwelling warm equatorial Kelvin waves (Lengaigne et al., 2004; Chen et al., 2014, Chen et al., 2016b, Chen et al., 2016c). In addition, the spring cyclonic anomaly over the subtropical North Pacific would lead to SST warming over the subtropical central North Pacific (Figure 4A) via modulating surface heat flux (dominated by the surface latent heat flux). Specifically, the southwesterly wind anomalies over the subtropical central North Pacific oppose the mean northeasterly trade winds, reduce the total wind speed (Figure 7C), and upward surface latent heat (Figure 7A) and, thus, result in spring SST warming there 

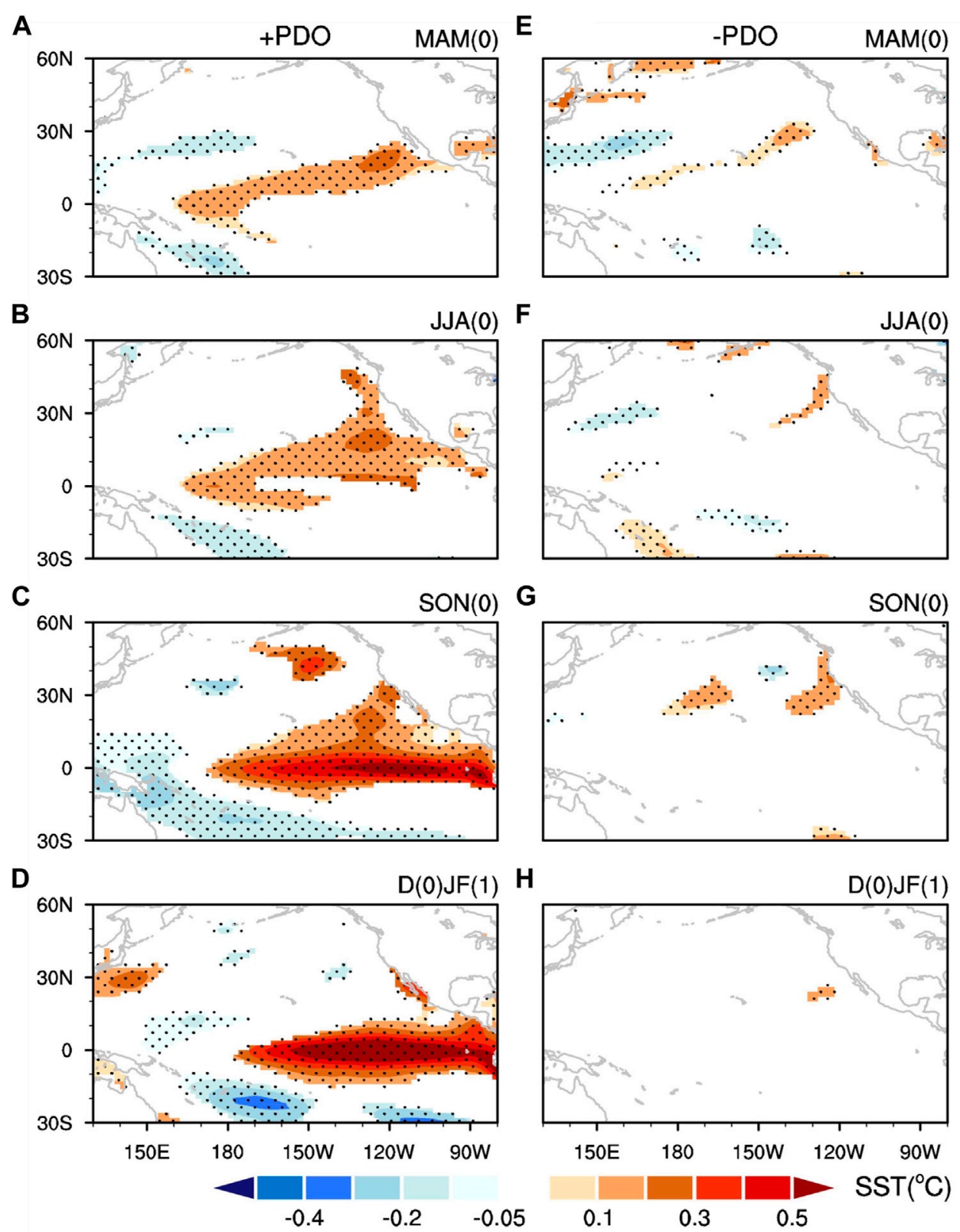

FIGURE 4|SST anomalies ( $\left.{ }^{\circ} \mathrm{C}\right)$ in (A,E) spring [MAM(O)], (B,F) summer [JJA(O)]), (C,G) autumn [SON(0)], and (D,H) winter [D(0)JF(1)] regressed upon the spring AO index for the (left column) +PDO and (right column) -PDO years. We only show the SST anomalies that are significant at the 95\% confidence level.

(Figure 4A), suggestive of the wind-evaporation-SST (WES) feedback (Xie and Philander 1994).

The spring AO-related SST anomalies in the subtropical North Pacific for the $+\mathrm{PDO}$ years bear a close resemblance to that related to the North Pacific Meridional Mode (PMM) (Chiang and Vimont 2004; Chang et al., 2007; Zheng et al., 2021), which is the dominant mode of air-sea coupling system over the subtropical Northeastern Pacific and is suggested to be an important channel in relaying impact of the extratropical forcings on the tropical ENSO events (Xie and Philander 1994; Chiang and Vimont 2004; Chang et al., 2007). This suggests that spring AO can exert impacts on the following winter ENSO via modulating the PMM for the +PDO years. In particular, the spring AO-generated SST warming in the subtropical central North Pacific leads to an increase in the atmospheric heating there (indicated by positive precipitation anomalies in Figure 5A). The enhanced atmospheric heating over the subtropical central North Pacific (Figure 5A) could maintain the spring AO-induced subtropical cyclonic anomaly (Figure 3A) via Gill-type atmospheric response, (Gill, 1980) which in turn maintains the SST warming in the subtropical central North Pacific (Figure 4A). The spring AO-related SST warming 

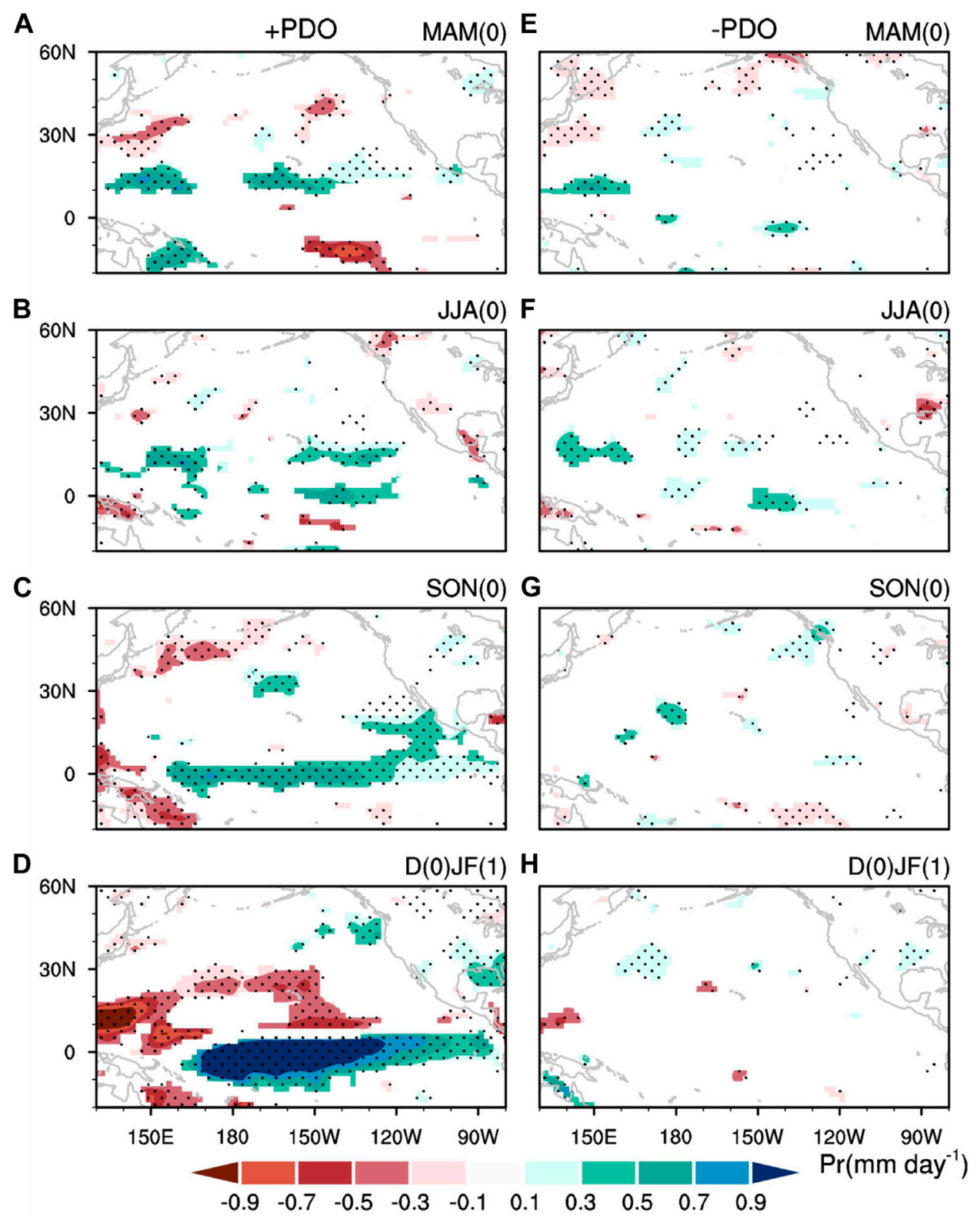

FIGURE 5 | As in Figure 4, but for precipitation anomalies $\left(\mathrm{mm}^{\text {day }}{ }^{-1}\right)$. Stippling regions indicate precipitation anomalies significant at the $95 \%$ confidence level.

maintains and further extends southward to the tropical central Pacific in the following summer via the WES feedback mechanism (Figure 4B). Then, the tropical SST warming can develop to an El Niño-like warming in the following winter via the Bjerknes-like positive air-sea interaction (Figures 3B-D, Figures 4B-D, and Figures 5B-D) (Bjerknes 1969).

In brief summary, during $+\mathrm{PDO}$ years, spring $\mathrm{AO}$ can induce a strong cyclonic anomaly over the subtropical North Pacific via wave-mean flow interaction. On one hand, this cyclonic anomaly could directly induce strong westerly wind anomalies over the tropical western Pacific and impact following winter ENSO occurrence via triggering eastward propagating warm equatorial Kelvin wave. On the other hand, the cyclonic anomaly generated by the spring AO could induce a PMMlike SST warming in the subtropical North Pacific, which further expand southward to the tropical central Pacific via the WES feedback mechanism and thus impact following winter ENSO via tropical positive air-sea interaction.

For the -PDO years, significant westerly wind anomalies in spring can be seen north of $60^{\circ} \mathrm{N}$ during positive phase of the spring $\mathrm{AO}$ (Figure 3E), similar to that for the $+\mathrm{PDO}$ years (Figure 3A). However, atmospheric anomalies over the North Pacific, especially the cyclonic anomalies over the subtropical North Pacific and westerly wind anomalies over the tropical western Pacific are very weak for the -PDO years. As such, the weak cyclonic anomalies (Figure 3E) could not induce clear 

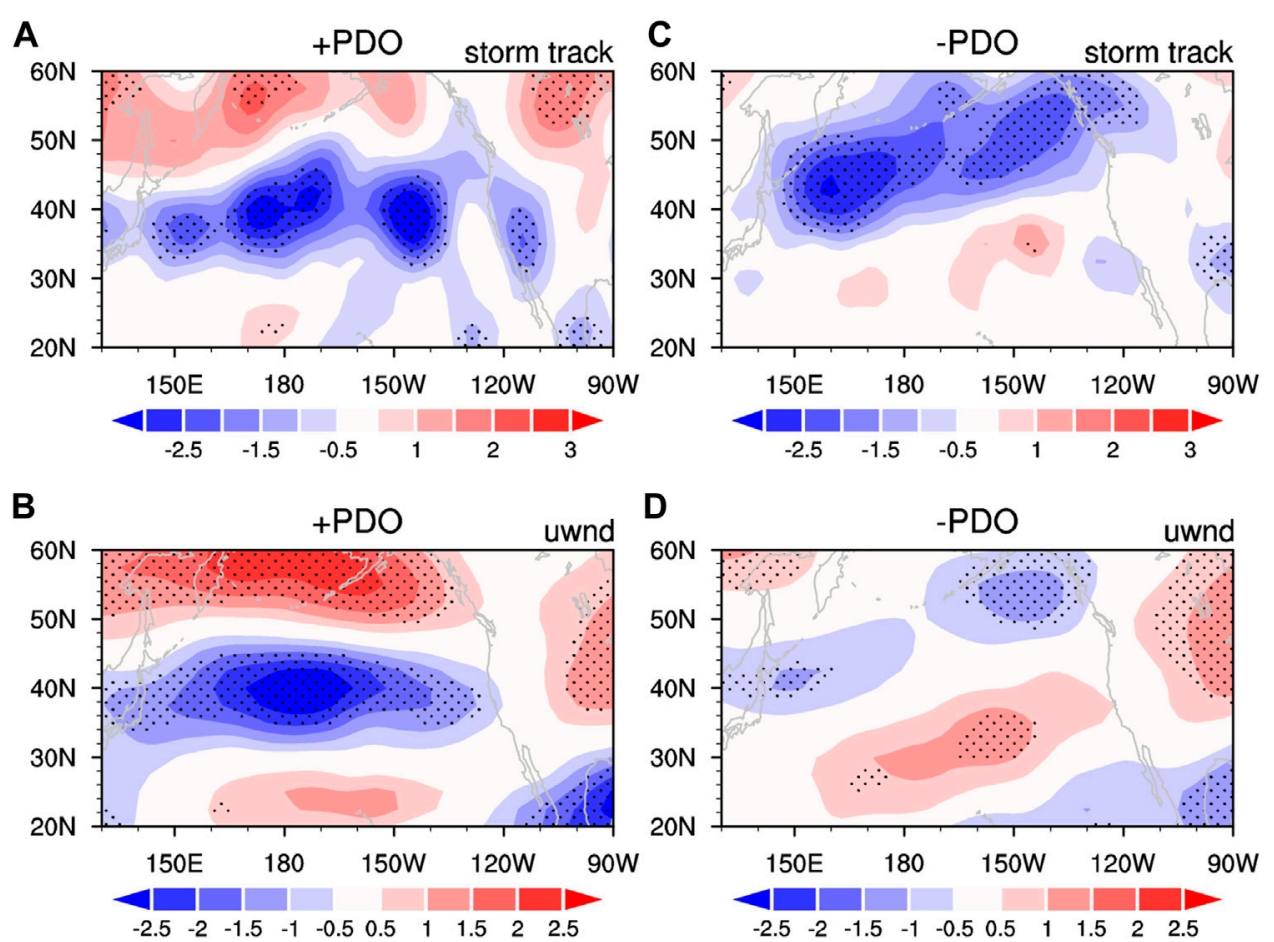

FIGURE 6 | Surface latent heat flux anomalies $\left(\mathrm{W} \mathrm{m}^{-2}\right)$ in spring regressed upon the spring AO index for the (A) +PDO and (B) -PDO years, respectively. (C,D) are as in $(\mathbf{A}, \mathbf{B})$, but for surface wind speed anomalies $\left(\mathrm{m} \mathrm{s}^{-1}\right)$. We only show the values that are significant at the $95 \%$ confidence level.
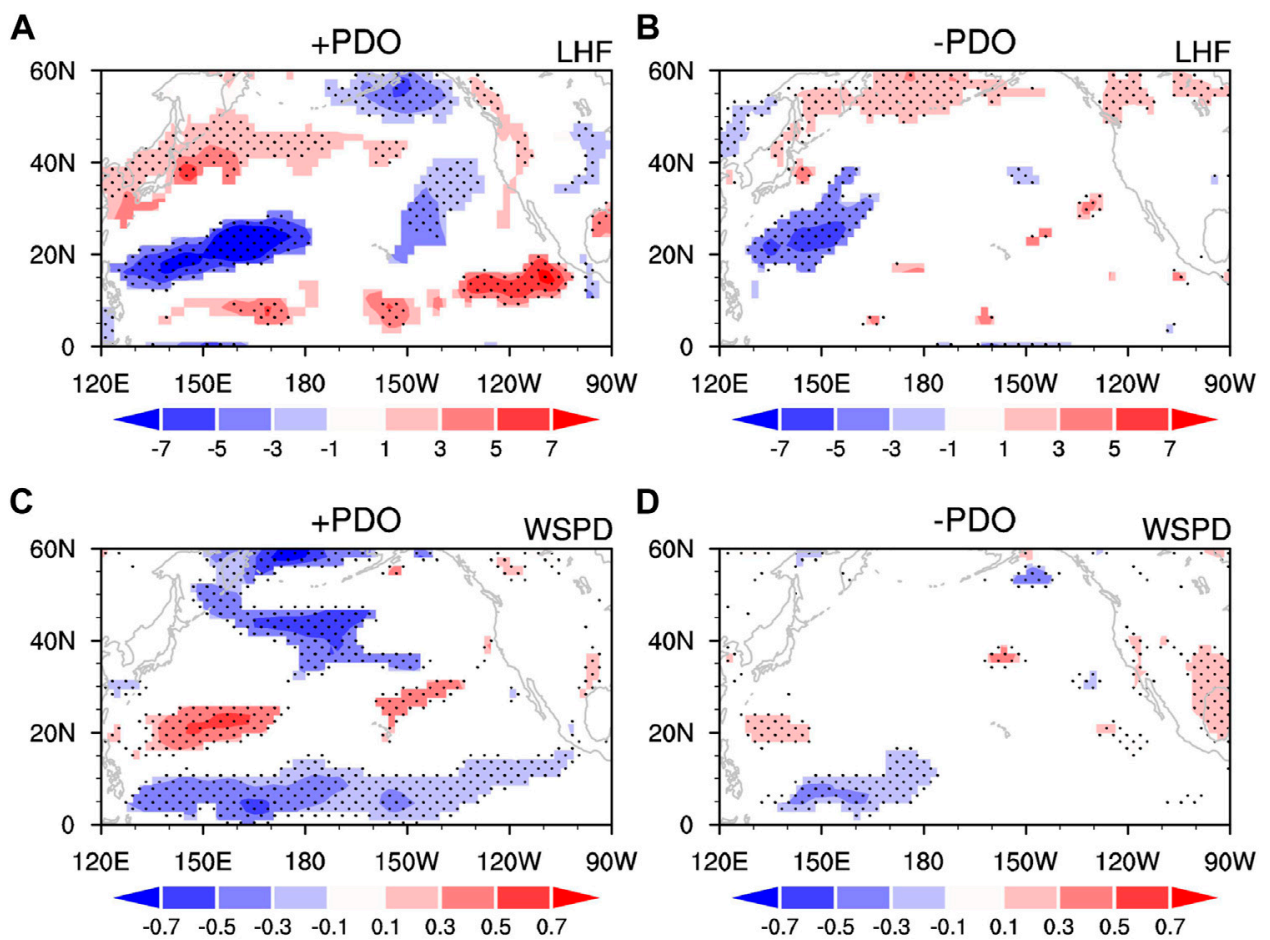

FIGURE 7 | Storm track anomalies $(\mathrm{m})$ of $200 \mathrm{hPa}$ in spring regressed upon the spring AO index for the (A) +PDO and (B) -PDO years, respectively. (C,D) are as in (A,B), but for $200 \mathrm{hPa}$ zonal wind anomalies $\left(\mathrm{m} \mathrm{s}^{-1}\right)$. 

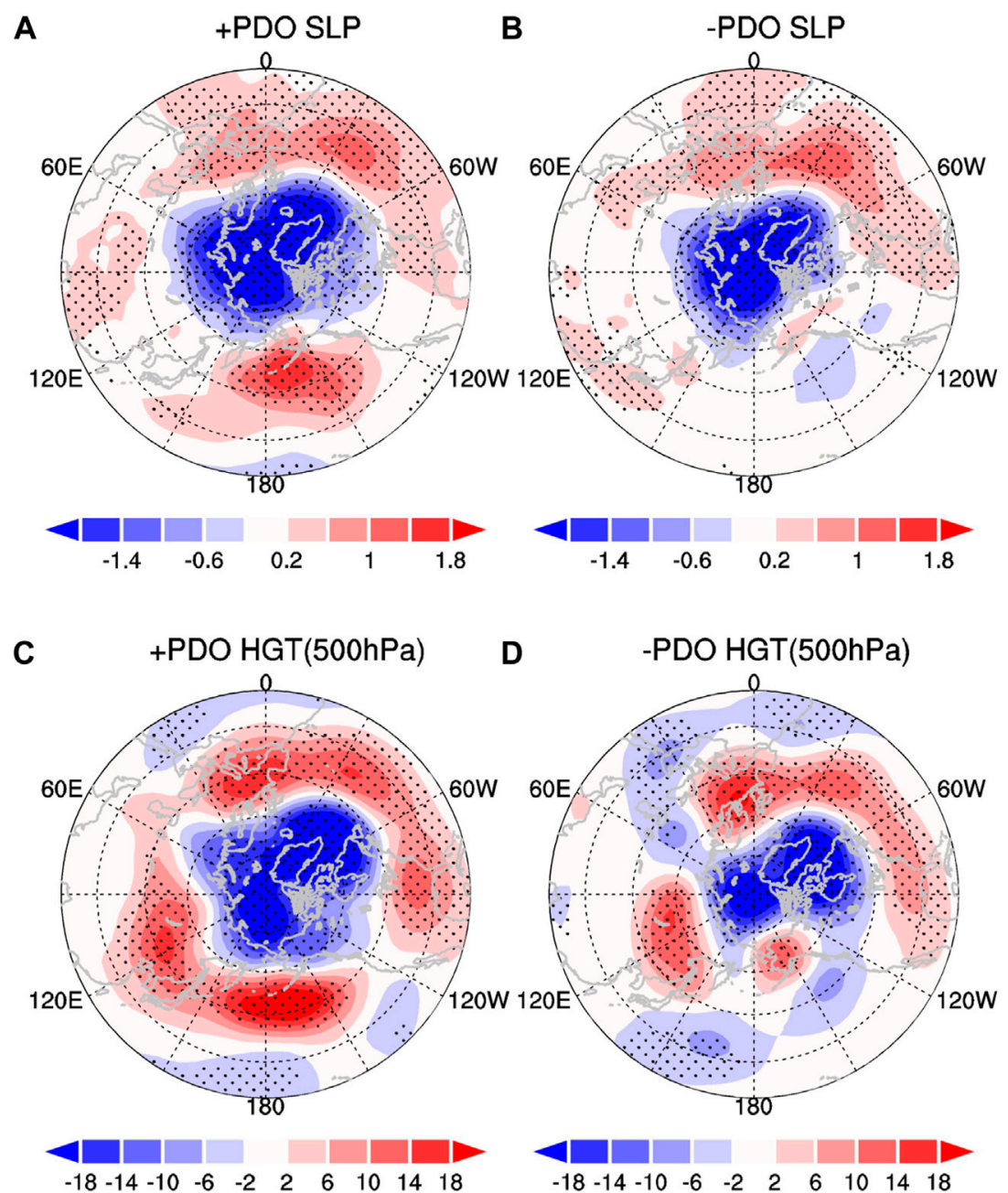

FIGURE 8 | Sea level pressure (SLP) anomalies ( $\mathrm{hPa}$ ) in spring regressed upon the spring AO index for the (A) +PDO and (B) -PDO years, respectively. (C,D) are as in (A,B), but for $500 \mathrm{hPa}$ geopotential height anomalies (m).

spring SST warming and atmospheric heating in the subtropical North Pacific (Figures $4 \mathrm{E}$ and $\mathbf{5 E}$ ) due to the weak surface wind speed and surface heat flux anomalies (Figures 7B,D). Therefore, the spring AO cannot exert clear impacts on the SST and atmospheric circulation over the tropical Pacific and, thus, have weak influences on the ENSO.

The above analysis indicates that the PDO has a notable influence on the spring AO-winter ENSO connection via changing the spring AO-related atmospheric anomalies over the North Pacific. In particular, the North Pacific component of the spring AO (i.e., the anticyclonic anomaly over the midhigh-latitudes North Pacific) and the generated cyclonic anomalies to its south side over the subtropical North Pacific are much weaker for the $-\mathrm{PDO}$ than the $+\mathrm{PDO}$ years, which can also be confirmed in Figure 8 showing regressions of the spring SLP and 500-hPa geopotential height anomalies upon the spring AO index. For both +PDO and -PDO, significant positive SLP and geopotential height anomalies are apparent over the North Atlantic, and marked negative SLP and geopotential height anomalies appear over the Arctic (Figure 8). However, the positive SLP and geopotential height anomalies over mid-highlatitudes North Pacific are much stronger for the +PDO than -PDO years (Figures 7A,B).

Studies have indicated that the interaction between synopticscale eddy and low-frequency mean flow plays an important role for the formation and maintenance of the spring AO-related atmospheric anomalies over North Pacific (Lau 1988; Chen et al., 2014, Chen et al., 2015). The weaker atmospheric anomalies related to the spring AO over the North Pacific for the -PDO years imply a weaker wave-mean flow interaction and a weaker feedback of synoptic-scale eddy to mean flow compared with those for the $+\mathrm{PDO}$ years. Feedback strength of the synoptic scale eddy to mean flow has a close connection with the climatological intensity of the storm track as has been demonstrated by previous studies (Jin et al., 2006a, Jin et al., 2006b; Jin, 2010; Chen et al., 2015). In particular, if strength of the low-frequency mean flow is similar, feedback strength of the synoptic scale eddy activity to mean flow is much stronger during the periods with stronger 


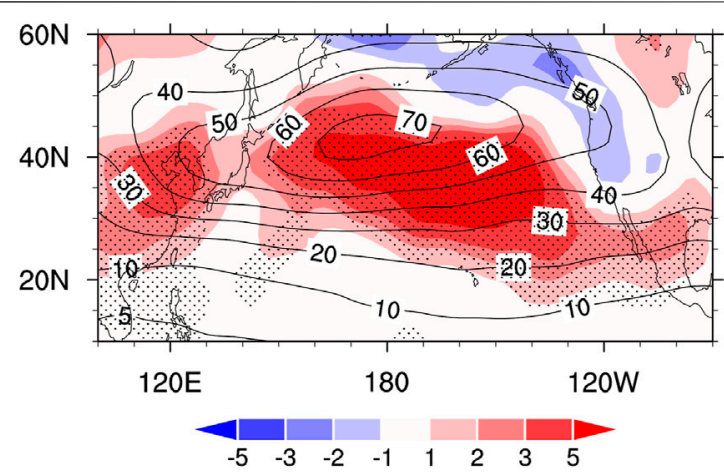

FIGURE 9 | Climatology of the spring 200-hPa storm track (contours, m) over 1950-2019. Shadings indicate differences in the climatology of spring storm track (shadings, $\mathrm{m}$ ) between +PDO and -PDO years. Differences that are significantly different from zero at the 95\% confidence level are stippled.

climatological storm track intensity, and vice versa (Chen et al., 2015, Chen et al., 2017). Climatology of the spring storm track activity over 1950-2019 (indicated by the contours) as well as the difference in the spring mean storm track between $+\mathrm{PDO}$ and -PDO years (indicated by the shadings) are shown in Figure 9. Maximum center of the climatology of spring storm track appears over mid-latitudes North Pacific around $45^{\circ} \mathrm{N}, 180^{\circ} \mathrm{E}$ (Figure 9). In addition, the difference map between + PDO and -PDO years shows significant positive storm track anomalies over North Pacific around $25^{\circ}-45^{\circ} \mathrm{N}$ This indicates that the North Pacific storm track intensity in spring is much stronger and shifts southward during +PDO than -PDO. Therefore, according to the findings of previous studies (Jin et al., 2006a, Jin et al., 2006b; Jin, 2010; Chen et al., 2015), stronger climatological storm track over North Pacific during +PDO years would lead to stronger feedback of synoptic-scale eddy activities to low frequency mean flow. This explains the stronger atmospheric anomalies over North Pacific in association with the spring AO and, thus, the stronger impact of the spring AO on the following winter ENSO for the +PDO years than the -PDO years.

Then, how can the PDO modulate the intensity of the spring storm track over North Pacific? Studies have indicated that change in the storm track intensity is closely related to change in the mean meridional gradient of low-level temperature (Lindzen and Farrell 1980; Hoskins and Valdes 1990; Penny et al., 2010; Lee et al., 2012; Chen et al., 2015). Increase in the meridional gradient of low-level temperature is favorable for baroclinic growth of the synoptic scale eddy and lead to increase in the storm track (Lindzen and Farrell 1980; Hoskins and Valdes 1990; Penny et al., 2010; Chen et al., 2015). Differences in the spring mean SST and air temperature at $100-\mathrm{hPa}$ between +PDO and -PDO years are shown in Figures 10A, B, respectively. Spatial structure of the SST difference is similar to that of the $1,000-\mathrm{hPa}$ air temperature difference. Mean SST and $1,000-\mathrm{hPa}$ air temperature is significantly stronger along west coast of North America with a southwestward extension to the tropical central-eastern Pacific and significantly weaker to the east of Japan around $30^{\circ}-40^{\circ} \mathrm{N}$
(Figure 10). Hence, the mean meridional gradient of low-level temperature over the subtropical North Pacific is much larger for + PDO than $-\mathrm{PDO}$ years. This suggests that PDO could modulate spring storm track intensity via modulating the mean meridional temperature gradient.

\section{SUMMARY}

Previous studies indicated that the spring AO has a significant impact on the following winter ENSO, but such impact is unstable. In this study, we reveal that the PDO acts as one of the important factors in modulating the spring AO-winter ENSO connection. When PDO is in its positive phase, spring AO has a pronounced impact on the following winter ENSO. By contrast, during the negative PDO phase, the linkage between the spring $\mathrm{AO}$ and the following winter ENSO is not robust.

We further examine the factors for the notable modulation effect of the PDO on the spring AO-winter ENSO connection. During $+\mathrm{PDO}$ years, a significant anticyclonic circulation anomaly is seen over mid-high-latitudes North Pacific and a pronounced cyclonic circulation anomaly is found over subtropical North Pacific. This leads to significant westerly wind anomalies over the tropical western-central Pacific, which further impacts the following winter ENSO occurrence via triggering eastward propagating and downwelling Kelvin wave. In addition, the subtropical cyclonic anomaly induces SST warming in the subtropical central North

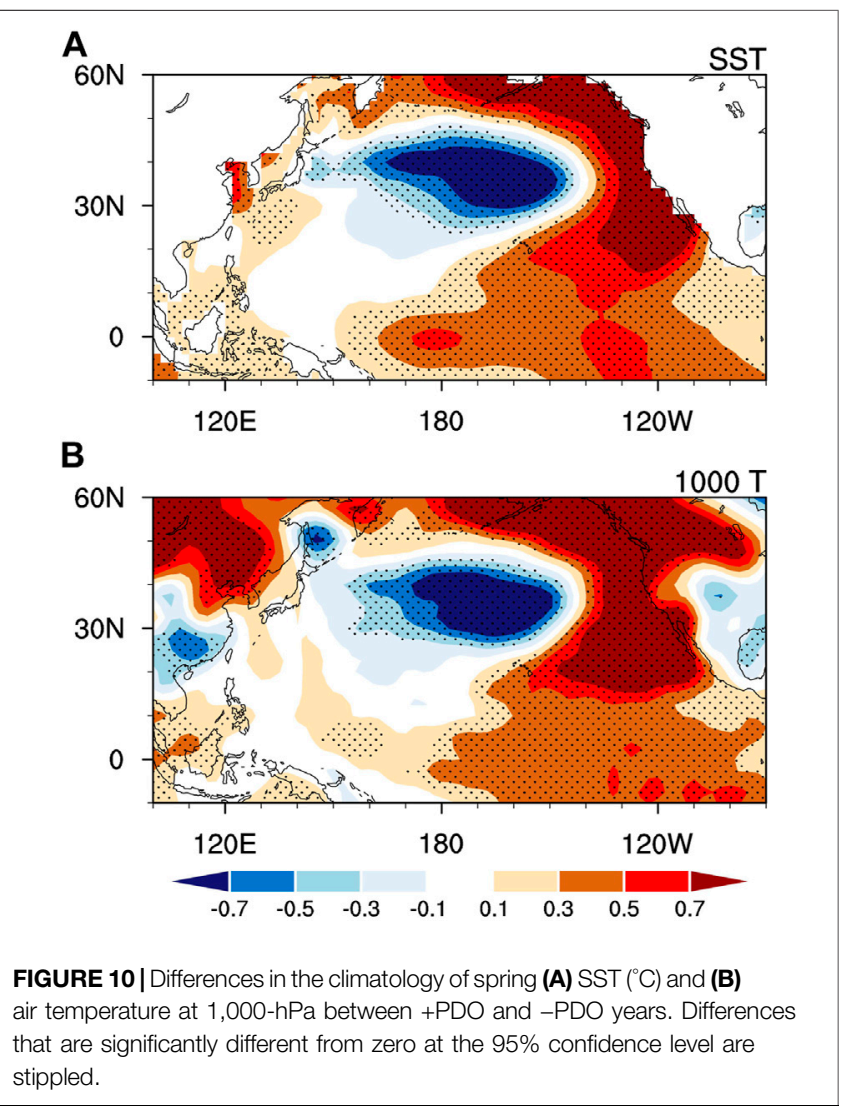


Pacific, resembling the PMM pattern, via modulating surface latent heat flux. The subtropical PMM-like SST warming maintains and extends southward to the tropical central Pacific via WES feedback mechanism, which further impact following winter ENSO occurrence through the tropical air-sea interaction. However, for the -PDO years, the atmospheric anomalies over the North Pacific related to the spring AO are much weaker. Correspondingly, the SST warming and atmospheric heating anomalies over the North Pacific are weak. As such, the spring AO has a weak impact on the following winter ENSO.

Further analysis shows that the spring storm track activity over the North Pacific is much stronger during +PDO years than that during -PDO years. Stronger climatological spring storm track activity during +PDO leads to a stronger eddy feedback to lowfrequency mean flow, which explains stronger atmospheric anomalies over the North Pacific in association with the AO. In addition, it is suggested that PDO could modulate the spring North Pacific storm track intensity via changing the mean meridional gradient of the low-level temperature, with much larger mean meridional temperature gradient during $+\mathrm{PDO}$ than $-\mathrm{PDO}$ years.

\section{REFERENCES}

Alexander, M. A., Bladé, I., Newman, M., Lanzante, J. R., Lau, N. C., and Scott, J. D. (2002). The Atmospheric Bridge: The Influence of ENSO Teleconnections on Air-Sea Interaction over the Global Oceans. J. Clim. 15, 2205-2231. doi:10. 1175/1520-0442(2002)015<2205:tabtio >2.0.co;2

Alexander, M. A., Vimont, D. J., Chang, P., and Scott, J. D. (2010). The Impact of Extratropical Atmospheric Variability on ENSO: Testing the Seasonal Footprinting Mechanism Using Coupled Model Experiments. J. Clim. 23, 2885-2901. doi:10.1175/2010jcli3205.1

Barnett, T. P. (1983). Interaction of the Monsoon and Pacific Trade Wind System at Interannual Time Scales Part I: the Equatorial Zone. Mon. Wea. Rev. 111, 756-773. doi:10.1175/1520-0493(1983)111<0756:iotmap >2.0.co;2

Bjerknes, J. (1969). Atmospheric Teleconnections from the Equatorial Pacificl. Mon. Wea. Rev. 97, 163-172. doi:10.1175/1520-0493(1969)097<0163:atftep >2.3.co;2

Budikova, D. (2005). Impact of the Pacific Decadal Oscillation on Relationships between Temperature and the Arctic Oscillation in the USA in winter. Clim. Res. 29, 199-208. doi:10.3354/cr029199

Cai, M., Yang, S., Van Den Dool, H. M., and Kousky, V. E. (2007). Dynamical Implications of the Orientation of Atmospheric Eddies: a Local Energetics Perspective. Tellus A: Dynamic Meteorology and Oceanography 59, 127-140. doi:10.1111/j.1600-0870.2006.00213.x

Chang, E. K. M., and Fu, Y. (2002). Interdecadal Variations in Northern Hemisphere winter Storm Track Intensity. J. Clim. 15, 642-658. doi:10. 1175/1520-0442(2002)015<0642:ivinhw>2.0.co;2

Chang, P., Zhang, L., Saravanan, R., Vimont, D. J., Chiang, J. C. H., Ji, L., et al. (2007). Pacific Meridional Mode and El Niño-Southern Oscillation. Geophys. Res. Lett. 34 (6), L16608. doi:10.1029/2007gl030302

Chen, D., and Lian, T. (2020). Frontier of El Niño-Southern Oscillation Research. Chin. Sci. Bull. 65, 4001-4003. doi:10.1360/tb-2020-1219

Chen, D., Lian, T., Fu, C., Cane, M. A., Tang, Y., Murtugudde, R., et al. (2015). Strong Influence of westerly Wind Bursts on El Niño Diversity. Nat. Geosci 8 (5), 339-345. doi:10.1038/ngeo2399

Chen, L., Li, T., Wang, B., and Wang, L. (2016b). Formation Mechanism for 2015/ 16 Super El Niño. Sci. Rep. 7, 2975. doi:10.1038/s41598-017-02926-3

Chen, L., Li, T., Yu, Y., and Behera, S. (2016a). A Possible Explanation for the Divergent Projection of ENSO Amplitude Change under Global Warming. Clim. Dynam. 49, 3799-3811.

Chen, L., Wang, L., Li, T., and Liu, J. (2019a). Drivers of Reduced ENSO Variability in Mid-holocene in a Coupled Model. Clim. Dyn. 52, 5999-6014. doi:10.1007/ s00382-018-4496-5

\section{DATA AVAILABILITY STATEMENT}

The original contributions presented in the study are included in the article/Supplementary Material. Further inquiries can be directed to the corresponding author.

\section{AUTHOR CONTRIBUTIONS}

SC designed the research, performed the analysis, and wrote the manuscript. All authors discussed the results and revised the manuscript.

\section{FUNDING}

This study is supported by the National Natural Science Foundation of China (Grant 42175039) and the Scientific Research Fund of the Second Institute of Oceanography, Ministry of Natural Resources (Grant QNYC 2001).

Chen, L., Zheng, W., and Braconnot, P. (2019b). Towards Understanding the Suppressed ENSO Activity during Mid-holocene in PMIP2 and PMIP3 Simulations. Clim. Dyn. 53, 1095-1110. doi:10.1007/s00382-019-04637-z

Chen, S., Chen, W., and Wei, K. (2013). Recent Trends in winter Temperature Extremes in Eastern China and Their Relationship with the Arctic Oscillation and ENSO. Adv. Atmos. Sci. 30, 1712-1724. doi:10.1007/ s00376-013-2296-8

Chen, S., Chen, W., Wu, R., Yu, B., and Graf, H.-F. (2020c). Potential Impact of Preceding Aleutian Low Variation on El Niño-Southern Oscillation during the Following Winter. J. Clim. 33, 3061-3077. doi:10.1175/jcli-d-19-0717.1

Chen, S., Chen, W., and Yu, B. (2017). The Influence of Boreal spring Arctic Oscillation on the Subsequent winter ENSO in CMIP5 Models. Clim. Dyn. 48, 2949-2965. doi:10.1007/s00382-016-3243-z

Chen, S. F., Wu, R., Chen, W., and Yu, B. (2020b). Influence of winter Arctic Sea Ice Concentration Change on the El Niño-Southern Oscillation in the Following winter. Clim. Dynam. 54 (1), 741-757. doi:10.1007/s00382-019-05027-1

Chen, S. F., Wu, R., Chen, W., and Yu, B. (2020a). Recent Weakening of the Linkage between the spring Arctic Oscillation and the Following winter El Niño-Southern Oscillation. Clim. Dynam. 54 (1), 53-67. doi:10.1007/s00382019-04988-7

Chen, S., Wu, R., Chen, W., Yu, B., and Cao, X. (2016c). Genesis of westerly Wind Bursts over the Equatorial Western Pacific during the Onset of the strong 20152016 El Niño. Atmos. Sci. Lett. 17, 384-391. doi:10.1002/asl.669

Chen, S., and Wu, R. (2018). Impacts of winter NPO on Subsequent winter ENSO: Sensitivity to the Definition of NPO index. Clim. Dyn. 50, 375-389. doi:10.1007/ s00382-017-3615-Z

Chen, S., Yu, B., and Chen, W. (2014). An Analysis on the Physical Process of the Influence of AO on ENSO. Clim. Dyn. 42, 973-989. doi:10.1007/s00382-0121654-z

Chen, S., Yu, B., and Chen, W. (2015). An Interdecadal Change in the Influence of the spring Arctic Oscillation on the Subsequent ENSO Around the Early 1970s. Clim. Dyn. 44, 1109-1126. doi:10.1007/s00382-014-2152-2

Chen, W., Graf, H. F., and Huang, R. H. (2000). The Interannual Variability of East Asian winter Monsoon and its Relation to the Summer Monsoon. Adv. Atmos. Sci. 17, 48-60.

Cheung, H. N., Zhou, W., Mok, H. Y., and Wu, M. C. (2012). Relationship between Ural-Siberian Blocking and the East Asian Winter Monsoon in Relation to the Arctic Oscillation and the El Niño-Southern Oscillation. J. Clim. 25, 4242-4257. doi:10.1175/jcli-d-11-00225.1

Chiang, J. C. H., and Vimont, D. J. (2004). Analogous Pacific and Atlantic Meridional Modes of Tropical Atmosphere-Ocean Variability ${ }^{\star}$. J. Clim. 17, 4143-4158. doi:10.1175/jcli4953.1 
Choi, K. S., Wu, C. C., and Byun, H. R. (2012). Possible Connection between Summer Tropical Cyclone Frequency and spring Arctic Oscillation over East Asia. Clim. Dyn. 38, 2613-2629. doi:10.1007/s00382-011-1088-z

Ding, R. Q., Li, J. P., and Tseng, Y. H. (2015). The Impact of South Pacific Extratropical Forcing on ENSO and Comparisons with the North Pacific. Clim. Dynam. 44, 2017-2034. doi:10.1007/s00382-014-2303-5

Ding, Y., Liu, Y., Liang, S., Ma, X., Zhang, Y., Si, D., et al. (2014). Interdecadal Variability of the East Asian winter Monsoon and its Possible Links to Global Climate Change. J. Meteorol. Res. 28, 693-713. doi:10.1007/s13351-014-4046-y

Duchon, C. E. (1979). Lanczos Filtering in One and Two Dimensions. J. Appl. Meteorol. 18, 1016-1022. doi:10.1175/1520-0450(1979)018<1016:lfioat $>2.0$. $\mathrm{co} ; 2$

Fang, X., and Xie, R. (2020). A Brief Review of ENSO Theories and Prediction. Sci. China Earth Sci. 63 (4), 476-491. doi:10.1007/s11430-019-9539-0

Gill, A. E. (1980). Some Simple Solutions for Heat-Induced Tropical Circulation. Q.J R. Met. Soc. 106, 447-462. doi:10.1002/qj.49710644905

Gong, D. Y., Yang, J., Kim, S. J., Gao, Y., Guo, D., Zhou, T., et al. (2011). Spring Arctic Oscillation-East Asian Summer Monsoon Connection through Circulation Changes over the Western North Pacific. Clim. Dyn. 37, 2199-2216. doi:10.1007/s00382-011-1041-1

Horel, J. D., and Wallace, J. M. (1981). Planetary-scale Atmospheric Phenomena Associated with the Southern Oscillation. Mon. Wea. Rev. 109, 813-829. doi:10. 1175/1520-0493(1981)109<0813:psapaw>2.0.co;2

Hoskins, B. J., and Valdes, P. J. (1990). On the Existence of Storm-Tracks. J. Atmos. Sci. 47, 1854-1864. doi:10.1175/1520-0469(1990)047<1854:oteost $>2.0 . c 0 ; 2$

$\mathrm{Hu}$, K., Huang, G., Huang, P., Kosaka, Y., and Xie, S.-P. (2021). Intensification of El Niño-Induced Atmospheric Anomalies under Greenhouse Warming. Nat. Geosci. 14, 377-382. doi:10.1038/s41561-021-00730-3

Hu, P., Chen, W., Chen, S., Liu, Y., and Huang, R. (2020). Extremely Early Summer Monsoon Onset in the South China Sea in 2019 Following an El Niño Event. Mon. Wea. Rev. 148, 1877-1890. doi:10.1175/mwr-d-19-0317.1

Huang, B., Thorne, P. W., Banzon, V. F., Boyer, T., Chepurin, G., Lawrimore, J. H., et al. (2017). Extended Reconstructed Sea Surface Temperature, Version 5 (ERSSTv5): Upgrades, Validations, and Intercomparisons. J. Clim. 30 (20), 8179-8205. doi:10.1175/jcli-d-16-0836.1

Huang, R. H., Chen, W., Yang, B. L., and Zhang, R. H. (2004). Recent Advances in Studies of the Interaction between the East Asian winter and Summer Monsoons and ENSO Cycle. Adv. Atmos. Sci. 21, 407-424. doi:10.1007/ bf02915679

Huang, R., Zhang, R., and Yan, B. (2001). Dynamical Effect of the Zonal Wind Anomalies over the Tropical Western Pacific on ENSO Cycles. Sci. China Ser. D-earth Sci. 44 (12), 1089-1098. doi:10.1007/bf02906865

Jin, F. F. (1997). An Equatorial Ocean Recharge Paradigm for ENSO. Part I: Conceptual Model. J. Atmos. Sci. 54, 811-829. doi:10.1175/1520-0469(1997) $054<0811$ :aeorpf $>2.0$. co; 2

Jin, F. F. (2010). Eddy-induced Instability for Low-Frequency Variability. J. Atmos. Sci. 67, 1947-1964. doi:10.1175/2009jas3185.1

Jin, F. F., Pan, L. L., and Watanabe, M. (2006a). Dynamics of Synoptic Eddy and Low-Frequency Flow Interaction. Part I: A Linear Closure. J. Atmos. Sci. 63, 1677-1694. doi:10.1175/jas3715.1

Jin, F. F., Pan, L. L., and Watanabe, M. (2006b). Dynamics of Synoptic Eddy and Low-Frequency Flow Interaction. Part II: A Theory for Low-Frequency Modes. J. Atmos. Sci. 63, 1695-1708. doi:10.1175/jas3716.1

Kalnay, E., Kanamitsu, M., Kistler, R., Collins, W., Deaven, D., Gandin, L., et al. (1996). The NCEP/NCAR 40-year Reanalysis Project. Bull. Amer. Meteorol. Soc. 77, 437-471. doi:10.1175/1520-0477(1996)077<0437:tnyrp >2.0.co;2

Kim, J. W., Yeh, S. W., and Chang, E. C. (2014). Combined Effect of El NiñoSouthern Oscillation and Pacific Decadal Oscillation on the East Asian winter Monsoon. Clim. Dyn. 42, 957-971. doi:10.1007/s00382-013-1730-z

Lau, N. C. (1988). Variability of the Observed Midlatitude Storm Tracks in Relation to Low-Frequency Changes in the Circulation Pattern. J. Atmos. Sci. 45, 2718-2743. doi:10.1175/1520-0469(1988)045<2718:votoms >2.0.co;2

Lee, S. S., Lee, J. Y., Wang, B., Ha, K. J., Heo, K. Y., Jin, F. F., et al. (2012). Interdecadal Changes in the Storm Track Activity over the North Pacific and North Atlantic. Clim. Dyn. 39, 313-327. doi:10.1007/s00382-011-1188-9

Lengaigne, M., Guilyardi, E., Boulanger, J.-P., Menkes, C., Delecluse, P., Inness, P., et al. (2004). Triggering of El Ni $\vartheta_{0}$ by westerly Wind Events in a Coupled
General Circulation Model. Clim. Dyn. 23, 601-620. doi:10.1007/s00382-0040457-2

Li, C. Y. (1990). Interaction between Anomalous winter Monsoon in East Asia and El Niño Events. Adv. Atmos. Sci. 7 (1), 36-46.

Limpasuvan, V., and Hartmann, D. L. (1999). Eddies and the Annular Modes of Climate Variability. Geophys. Res. Lett. 26, 3133-3136. doi:10.1029/ $1999 \mathrm{gl010478}$

Lindzen, R. S., and Farrell, B. (1980). A Simple Approximate Result for the Maximum Growth Rate of Baroclinic Instabilities. J. Atmos. Sci. 37, 1648-1654. doi:10.1175/1520-0469(1980)037<1648:asarft>2.0.co;2

Linkin, M. E., and Nigam, S. (2008). The north pacific Oscillation-West Pacific Teleconnection Pattern: Mature-phase Structure and winter Impacts. J. Clim. 21, 1979-1997. doi:10.1175/2007jcli2048.1

Lorenz, D. J., and Hartmann, D. L. (2003). Eddy-zonal Flow Feedback in the Northern Hemisphere winter. J. Clim. 16, 1212-1227. doi:10.1175/15200442(2003) $16<1212$ :effitn>2.0.co;2

Mantua, N. J., Hare, S. R., Zhang, Y., Wallace, J. M., and Francis, R. C. (1997). A Pacific Interdecadal Climate Oscillation with Impacts on salmon Production. Bull. Amer. Meteorol. Soc. 78, 1069-1079. doi:10.1175/1520-0477(1997) 078<1069:apicow $>2.0$. co;2

Min, Q., Su, J., and Zhang, R. (2017). Impact of the South and North Pacific Meridional Modes on the El Niño-Southern Oscillation: Observational Analysis and Comparison. J. Clim. 30, 1705-1720. doi:10.1175/jcli-d-16-0063.1

Nakamura, T., Tachibana, Y., Honda, M., and Yamane, S. (2006). Influence of the Northern Hemisphere Annular Mode on ENSO by Modulating westerly Wind Bursts. Geophys. Res. Lett. 33, L07709. doi:10.1029/2005gl025432

Neelin, J. D., Battisti, D. S., Hirst, A. C., Jin, F.-F., Wakata, Y., Yamagata, T., et al. (1998). ENSO Theory. J. Geophys. Res. 103, 14261-14290. doi:10.1029/ 97jc03424

Penny, S., Roe, G. H., and Battisti, D. S. (2010). The Source of the Midwinter Suppression in Storminess over the North Pacific. J. Clim. 23, 634-648. doi:10. 1175/2009jcli2904.1

Philander, S. G. (1990). El Niño, La Niña, and the Southern Oscillation, 46. London, UK: Academic Press, 289p.

Ren, H. L., Jin, F. F., Tian, B., and Scaife, A. A. (2016). Distinct Persistence Barriers in Two Types of ENSO. Geophys. Res. Lett. 43 (20), 10973-10979. doi:10.1002/ $2016 \mathrm{gl071015}$

Schopf, P. S., and Suarez, M. J. (1988). Vacillations in a Coupled OceanAtmosphere Model. J. Atmos. Sci. 45, 549-566. doi:10.1175/1520-0469(1988) $045<0549$ :viacom $>2.0$. co; 2

Song, L., Chen, S., Chen, W., and Chen, X. (2017). Distinct Impacts of Two Types of La Niña Events on Australian Summer Rainfall. Int. J. Climatol. 37, 2532-2544. doi:10.1002/joc.4863

Song, L., Li, Y., and Duan, W. (2016). The Influence of Boreal winter Extratropical North Pacific Oscillation on Australian spring Rainfall. Clim. Dyn. 47, 1181-1196. doi:10.1007/s00382-015-2895-4

$\mathrm{Su}, \mathrm{J} ., \mathrm{Li}, \mathrm{T}$., and Zhang, R. (2014). The Initiation and Developing Mechanisms of Central Pacific El Niños. J. Clim. 27 (12), 4473-4485. doi:10.1175/jcli-d-1300640.1

Tang, Y., Zhang, R.-H., Liu, T., Duan, W., Yang, D., Zheng, F., et al. (2018). Progress in ENSO Prediction and Predictability Study. Natl. Sci. Rev. 5 (6), 826-839. doi:10.1093/nsr/nwy105

Thompson, D. W. J., Lee, S., and Baldwin, M. P. (2003). Atmospheric Processes Governing the Northern Hemisphere Annular Mode/North Atlantic Oscillation. Geophys. Monogr. Am. Geophys. Union134, 81-112. doi:10.1029/134gm05

Thompson, D. W. J., and Wallace, J. M. (2000). Annular Modes in the Extratropical Circulation. Part I: Month-To-Month Variability*. J. Clim. 13, 1000-1016. doi:10.1175/1520-0442(2000)013<1000:amitec >2.0.co;2

Thompson, D. W. J., and Wallace, J. M. (1998). The Arctic Oscillation Signature in the Wintertime Geopotential Height and Temperature fields. Geophys. Res. Lett. 25, 1297-1300. doi:10.1029/98gl00950

Vimont, D. J., Battisti, D. S., and Hirst, A. C. (2001). Footprinting: A Seasonal Connection between the Tropics and Mid-latitudes. Geophys. Res. Lett. 28, 3923-3926. doi:10.1029/2001gl013435

Vimont, D. J., Wallace, J. M., and Battisti, D. S. (2003). The Seasonal Footprinting Mechanism in the Pacific: Implications for ENSO*. J. Clim. 16, 2668-2675. doi:10.1175/1520-0442(2003)016<2668:tsfmit >2.0.co;2 
Wallace, J. M., and Gutzler, D. S. (1981). Teleconnections in the Geopotential Height Field during the Northern Hemisphere winter. Mon. Wea. Rev. 109, 784-812. doi:10.1175/1520-0493(1981)109<0784:titghf $>2.0 . c 0 ; 2$

Wang, B., Wu, R., and Fu, X. (2000). Pacific-east Asian Teleconnection: How Does ENSO Affect East Asian Climate? J. Clim. 13, 1517-1536. doi:10.1175/15200442(2000)013<1517:peathd >2.0.co;2

Wang, L., Chen, W., and Huang, R. (2008). Interdecadal Modulation of PDO on the Impact of ENSO on the East Asian winter Monsoon. Geophys. Res. Lett. 35, L20702. doi:10.1029/2008gl035287

Wang, X., Wang, C., Zhou, W., Wang, D., and Song, J. (2011). Teleconnected Influence of North Atlantic Sea Surface Temperature on the El Niño Onset. Clim. Dynam. 37, 663-676. doi:10.1007/s00382-010-0833-z

Wei, K., Ouyang, C., Duan, H., Li, Y., Chen, M., Ma, J., et al. (2020). Reflections on the Catastrophic 2020 Yangtze River basin Flooding in Southern china. The Innovation 1. doi:10.1016/j.xinn.2020.100038

Xie, S. P., and Philander, S. G. H. (1994). A Coupled Ocean-Atmosphere Model of Relevance to the ITCZ in the Eastern Pacific. Tellus Ser. A-dyn. Meteorol. Oceanol. 46, 340-350. doi:10.1034/j.1600-0870.1994.t01-1-00001.x

Yang, X., and Huang, P. (2021). Restored Relationship between ENSO and Indian Summer Monsoon Rainfall Around 1999/2000. The Innovation 2, 100102. doi:10.1016/j.xinn.2021.100102

Yeh, S. W., Wang, X., Wang, C., and Dewitte, B. (2015). On the Relationship between the North Pacific Climate Variability and the central Pacific El Niño. J. Clim. 28 (2), 663-677. doi:10.1175/jcli-d-14-00137.1

Yu, B., and Zwiers, F. (2007). The Impact of Combined ENSO and PDO on the PNA Climate: a 1,000-year Climate Modeling Study. Clim. Dynam. 29, 837-851. doi:10.1007/s00382-007-0267-4

Yu, J. Y., Kim, S. T., and Lu, M. (2012). A Change in the Relationship between Tropical central Pacific SST Variability and the Extratropical Atmosphere Around 1990. Environ. Res. Lett. 7 (3), 034025. doi:10.1088/1748-9326/7/3/034025

Zhai, P. M., Rong, Y. U., Xuejuan, R., Yaqiang, W., Wenhui, X. U., Yanju, L., et al. (2016). The strong El Niño of 2015/16 and its Dominant Impacts on Global and China's Climate. J. Meteorol. Res. 30 (3), 283-297. doi:10.1007/s13351-0166101-3

Zhang, R. H., Sumi, A., and Kimoto, M. (1996). Impact of El Niño on the East Asian Monsoon: A Diagnostic Study of the '86/87 and ' $91 / 92$ Events. J. Meteorol. Soc. Jpn. 74 (1), 49-62. doi:10.2151/jmsj1965.74.1_49

Zhang, R. H., Yu, Y., Song, Z., Ren, H., Tang, Y., Qiao, F., et al. (2020). A Review of Progress in Coupled Ocean-Atmosphere Model Developments for ENSO Studies in China. J. Ocean Limnology 38 (4), 930-961. doi:10.1007/s00343020-0157-8
Zhang, W. J., Jin, F. F., Li, J. P., and Ren, H. L. (2011). Contrasting Impacts of Twotype El Niño over the Western North Pacific during Boreal Autumn. J. Meteorol. Soc. Jpn. 89, 563-569. doi:10.2151/jmsj.2011-510

Zhang, W. J., Jin, F. F., Ren, H. L., Li, J. P., and Zhao, J. X. (2012). Differences in Teleconnection over the North Pacific and Rainfall Shift over the USA Associated with Two Types of El Niño during Boreal Autumn. J. Meteorol. Soc. Jpn. 90, 535-552. doi:10.2151/jmsj.2012-407

Zhang, Y., Wallace, J. M., and Battisti, D. S. (1997). ENSO-like Interdecadal Variability: 1900-93. J. Clim. 10, 1004-1020. doi:10.1175/1520-0442(1997) $010<1004$ :eliv $>2.0$. co; 2

Zheng, Y., Chen, S., Chen, W., and Yu, B. (2021). Diverse Influences of spring Arctic Oscillation on the Following winter El Niño-Southern Oscillation in CMIP5 Models. Clim. Dynam. 56, 275-297. doi:10.1007/s00382-02005483-0

Zheng, Y. Q., Chen, W., and Chen, S. F. (2021). Intermodel Spread in the Impact of the Springtime Pacific Meridional Mode on Following-winter ENSO Tied to Simulation of the ITCZ in CMIP5/CMIP6. Geophys. Res. Lett. 48, e2021GL093945. doi:10.1029/2021gl093945

Zhou, W., and Chan, J. C. L. (2007). ENSO and South China Sea Summer Monsoon Onset. Int. J. Climatol. 27, 157-167. doi:10.1002/joc.1380

Zhou, W., Wang, X., Zhou, T. J., and Chan, J. C. L. (2007). Interdecadal Variability of the Relationship between the East Asian winter Monsoon and ENSO. Meteorol. Atmos. Phys. 98, 283-293. doi:10.1007/s00703-007-0263-6

Conflict of Interest: The authors declare that the research was conducted in the absence of any commercial or financial relationships that could be construed as a potential conflict of interest.

Publisher's Note: All claims expressed in this article are solely those of the authors and do not necessarily represent those of their affiliated organizations, or those of the publisher, the editors, and the reviewers. Any product that may be evaluated in this article, or claim that may be made by its manufacturer, is not guaranteed nor endorsed by the publisher.

Copyright () 2022 Chen, Chen, Ying, Zheng and Lan. This is an open-access article distributed under the terms of the Creative Commons Attribution License (CC BY). The use, distribution or reproduction in other forums is permitted, provided the original author(s) and the copyright owner(s) are credited and that the original publication in this journal is cited, in accordance with accepted academic practice. No use, distribution or reproduction is permitted which does not comply with these terms. 